Island Studies Journal, Vol. 4, No. 2, 2009, pp. 163-182

\title{
Island Words, Island Worlds: The Origins and Meanings of Words for 'Islands' in North-West Europe
}

Owe Ronström

University of Gotland

Visby, Gotland

Sweden

owe.ronstrom@hgo.se

\begin{abstract}
This paper proposes the notion that words mirror ideas, perspectives and worldviews. Etymologies and meanings of general words for 'islands' in a number of languages in North and West Europe are then discussed. Here, islands are shown to be etymologically constituted by the interplay between land and water, and which of these two is emphasized varies. In the third section, a number of Swedish island words are surveyed, in an attempt to illuminate the principle of linguistic relativity. Finally, the implications of these findings for island studies are discussed.
\end{abstract}

Keywords: archipelago, etymology, island, island studies, language, linguistic relativity, oppositions, snow, Swedish

(C) 2009 - Institute of Island Studies, University of Prince Edward Island, Canada.

\section{Introduction}

What is an island? The obvious answer: a word. What are words? Beautifully small and magically tensile forms, tools for thought and emotion. By expressing ourselves, we give form to the world. By defining and delimiting the conceivable, words give form to the knowable. When we make words our own, the world moves into us. We connect with those who lived before us, and our world-views and life-worlds are remade. Words are storehouses for knowledge and experiences accumulated over centuries, thereby practical entries to vast and elusive knowledge. In ever growing semantic clouds of accumulated meanings, we may find clues as to how seemingly disparate worlds are related, and to how people in distant places and times have understood their life-worlds.

These opening remarks on language and knowledge are inspired by a passage in an article on island definitions and typologies by geographer Stephen Royle. Reflecting over islandwords, Royle points out that it "is not unusual in the development of society and language for even a straightforward construct to require a variety of terms to capture its complexity if it is sufficiently important" (Royle, 2007: 36). This led me to investigate into islandwords. My questions are: What kind of a word is 'island'? What are the original meanings of words for 'islands' in different languages? What clues to world-views and life conditions can be found through an investigation of them? How are different island-words related? In the second section I will take a deeper look at a number of Swedish islandwords, in an attempt to illuminate Royle's point about the variety of terms required to 
capture the complexity even of a seemingly straightforward construct such as "the island". The questions are: do peoples in places with many islands also have many words for islands? In that case, do continental peoples also have few island-words? In the last section I discuss possible theoretical and methodological outcomes of the survey over islandwords, starting from the idea that islands, like languages, are systems constituted by series of differences.

\section{A Digression on Snow}

Royle's reflection over how the importance of a construct may correlated to the number of terms relates to a long-standing debate over the nature of the relation between society and language. Since at least half a century, Inuit words for snow have been used as the given example. So also in Royle's article, in which the quoted passage continues:

"[T]he best known example must be the categorization of "snow; into a multiplicity of different types, each with its own word, in Inuktitut and other Arctic languages" (Royle, 2007: 36).

It is today a widespread truth that while southerners have but a few words for snow, northerners, like the Inuit, have all the more such words. If you live up north, were there is lots of snow, and where even the subtlest variation in the type of snow can be a significant detail, extensive snow knowledge becomes necessary, even for survival. Since snow is a central and constitutive part of Nordic cultures, it will leave an imprint on Nordic languages. Language becomes a mirror of culture, and culture a mirror of local conditions.

The implication of this seemingly self-evident idea, is that every language, every group or nation creates its own culture. Among philosophers in $17^{\text {th }}$ and $18^{\text {th }}$ century Europe, the idea became a sharp-edged weapon in a radical break-up from a world-view that projected the world as principally God-given, unchangeable. Guided by, among others, Immanuel Kant and Johan Gottfried von Herder, the growing European bourgeoisie commenced its successful rebellion against the given order of things under slogans such as: "one country, one people, one language". What followed was radical cultural politics: since people of different nations talk and think differently, they should be ruled by themselves, and valued and judged according to their own standards.

During the first half of the $19^{\text {th }}$ Century, philosopher and linguist Wilhelm von Humboldt developed his theories about weltanschauung, or world-view, based on the idea that since humans are governed by language, think with and through language, thinking is impossible without a language (von Humboldt, 1836; also Modin \& Palm, 2003:1). It was as a student at Kiel University in the late 1870's, that the young Franz Boas came across the ideas of Kant and von Humboldt. In 1883 Boas travelled to Baffin Island, Northern Canada, to study Inuit language and culture. Later in the US, his pioneering studies among the natives of North America led him to the conclusion that these peoples not only lived and talked differently; they also seemed to think differently (Boas, 1911; Cole, 1999) 
Edward Sapir, one of Franz Boas' prominent pupils, developed the ideas about how worldviews influence and are influenced by language. Sapir's pupil, Benjamin Lee Whorf, took Sapir's ideas about language as a coherent system of signs that both mirrors and influence peoples' life-worlds even further, by studying how phenomena are categorized and organized by linguistic denomination. Whorf opposed the notion that language was a mere expression of something already formulated. Language is what gives form to the mind, he argued, it is at once the precondition and the limit for the speakers knowledge about the world, thereby also for their thinking about the world. The 'Sapir-Whorf-hypothesis' has become the standard caption for this principle of linguistic relativity: the idea that every language's grammar and lexicon mirrors a world-view (weltanschauung) that forms the speakers' way of thinking. ${ }^{1}$

From Herder and Kant, von Humboldt and Boas, to Sapir and Whorf, there is a track written in snow. It was a passage in the introduction to Franz Boas' Handbook of American Indian Language, published 1911, on the language of the Eskimos on Baffin Island, the Inuit in modern day Nunavut, that led Benjamin Whorf to Eskimo languages. In a much read article published 1940, Whorf noticed that Eskimos use a number of words for snow, which, he thought, reflect the importance and meaning of snow to them. In turn, the many words influence their ways of thinking, conceiving and categorising snow (Whorf, 1974; Modin \& Palm, 2003). The important point for Boas, Whorf and other linguists at the time, was not however the number of words, but the absence in Inuit of a single, general word for snow. ${ }^{2}$ Geoffrey Nunberg writes:

"[Whorf] concluded that the Eskimos were incapable of conceptualizing the general category. To an Eskimo, this all inclusive word would be almost unthinkable" (Nunberg, 1995:2; also Modin \& Palm, 2003).

There is but a small step from Eskimos, Greenlanders, or Inuit to other people's uses of words. That there are many - up to hundreds - of Inuit words for snow has become a common truth, ${ }^{3}$ just as there are 160 Bedouin words for camels and over 500 Italian words

1 'The Sapir-Whorf-hypotesis' is indeed a caption. It was never explicitly formulated by Edward Sapir or Benjamin Whorf (Modin \& Palm, 2003: 2f).

2 As Whorf points out, the relation between language, thought and culture may actually be stronger in grammatical structures, metaphors, metonyms and other tropes, than in vocabularies.

3 A reason why the many Inuit words for snow have become a common truth is that it has been the given example in textbooks on language and culture since at least the 1940's (Malm, 2009:170). In an article survey on Inuit words for snow in American newspapers, the American linguist Geoffrey Nunberg found that the factoid in many cases was embedded in a cultural critique: Eskimos (as he called them) may have many words for snow, but Americans have many words for drugs, violence, racism, fatigue, rape, road surfaces, silence, stubborn children, good women, laughter and what not. Nunberg notices a kind of competition in the background: the largest vocabulary wins. The idea seems to be that "with experience we might see the world more differentiated than we do" and that a "highly differentiated vocabulary betrays a familiarity with a variety of experience" (Nunberg, 1995:3). A rich vocabulary becomes a mark of ability to discriminate, which Enlightenment aesthetics theories made into "a synonym for "taste", and by the way, a mark of worldly accomplishment". Nunberg refers to a book by language columnist Richard Lederer, where he "puts the English vocabulary at "as much as two million" against estimates of 185.000 for German, 130.000 for Russian, and under 100.000 for the poor French". Following this logic, small and 'primitive' peoples' many words for certain phenomena, like the Inuit words for snow, can be used as a kind of cultural critique, a praising of the "noble savage". 
for pasta. ${ }^{4}$ But is this the case? Well, yes, there are many Inuit ways to talk about snow. And no, they do not have many words for snow, not more than the English do. ${ }^{5}$ Due to an extraordinarily productive peculiarity in the Eskimo-Aleut languages, to which Greenlandic, Inuktitut, Yupik and some others belong, from a few basic words and a number of suffixes it is possible to make up new words, one for every possible use. ${ }^{6}$ As the Scottish linguist Geoff Pullum remarks, the number of distinct words for snow you can derive from them "is not 50 or 150 or 1500 or a million, but simply unbounded. Only stamina sets a limit". 7

\section{Island Words and Etymologies}

Back to words used for 'island'. What are the original meanings of these words and how are the words related? Do "archipelagic" peoples have many words for islands? In that case, do they also have a single, general word?

The answer to the last of these questions is a simple yes. Of the well over twenty languages I have looked at, all have a single general or generic word for 'island'. The answers to the other questions, however are more complex. Here I confine myself to a preliminary survey of island-words in languages around the Baltic sea, and in some other languages with connections to and influences on this area. ${ }^{8}$ In this section, I will focus on the general words, starting with my native Swedish.

The general Swedish word for island is 'ö', The original meaning is "land by the water or surrounded by water". It is common in place-names, often denoting an elevation in a marsh or swamp. The word's roots is the ancient (proto-)Indo-European 'akua' ('akwā'), water, which gave Swedish also another short water-word, 'å', river or stream. Thus Öland and Åland, two of the larger islands/groups of islands in the Baltic sea, have the same linguistic root. 'Akua' became the proto-German 'ahwō' ('aujo'), thing on the water, with the adjective 'azwiō', 'ahwiō' or 'ahwjō', watery, from which the Gots formed their 'awi', still resounding in geographical terms and place-names, such as Scandinavia, Skåne ('Scania', in south Sweden) and Ahvio, a municipality north of Kotka, in south Finland (Hellquist, 1980: 1451f).

4 http://people.ischool.berkeley.edu/ nunberg/snow.html. A survey of articles on many words for snow is http://www.faktoider.nu/gronlandsk sno.html.

5 Boas listed only four words for snow among the Eskimos in Bffin Island. An article from 1927 lists 10 , and in 1984 Micheal Fortescue listed words for frozen water in West Greenlandic, among which over twenty refers to different forms of snow (Boas, 1991: 25-26; Malm, 2009: 181-182)

6 Eskimo-Aleut languages and a number of North-American languages belong to a unusual language type, often called polysyntetic languages, characterized by a tendency to incorporate many or all of the parts of a sentence into the verb. The result is few and long words (Andersson, 2001:30).

7 Pullum (1991) http://itre.cis.upenn.edu/ myl/languagelog/archives/000405.html. http://www.princeton.edu/ browning/snow.html, http://people.ischool.berkeley.edu/ nunberg/snow.html. A language which has many words for snow is (Lule-)Sami. Around a hundred are listed in Ryd's "Snö" ("Snow", 2001), about the Sami reindeer breeder Johan Rassa.

8 I am aware of the changes that might have occurred over time in meanings and usages. The diachronic dimension, however, is not explored in this paper. 
In Old High German, the word became 'ouwe' (island, but also water, stream) and in Middle Low German 'ou', 'ô', (island or watery pasture), still in use in certain contexts. In the $17^{\text {th }}$ century 'Eyland' was standard German, from 1876 written as 'Eiland'. The modern German 'insel' is a medieval inloan from Latin, first as 'İsila' (Old High German), and later as 'insul(e)' or 'insel(e)' (Middle High German). ${ }^{9}$ When 'insul-insel(e)' became the general island-word, from about the $19^{\text {th }}$ century, 'Eiland' took on new meaning: in poetic high language, an 'island not easily accessed; in vernacular German, a 'small island'. ${ }^{10}$

The Germanic root is apparent in Old Norse 'ey', island, also a low-lying land by water. We find it in Norwegian 'öy', Danish ' $\varnothing$ ', Faroese 'oyggj', Icelandic 'eyja', Pommerian 'Oie' and Frisian 'oog'. With the Vikings it became widespread, to Dutch 'eiland', German 'Eiland', Danish 'Ejland', English 'eyot', or 'ai' (small island in a river, especially in the river Thames), ${ }^{11}$ and to many places in the North Atlantic: Jersey (Gersoi, Jersoi) in the English Channel is "Geirr's island"; Whalsay, one of the Shetland isles, is the island of whales, Eriskay in the Outer Hebridies is "Erik's island", Rousay, one of the Orkney islands, is "Rolfs island". ${ }^{12}$ Also in Gotlandic (or Gutnish) 'åi' the German root is visible. In this old language, today spoken by around thousand persons mainly on the east coast of this Baltic island, we also find 'åilä', a small island or islet, and the practical verb 'åiä' ör 'öiä', which in the old days meant "to go fishing to Karlsöarna", two small islands along the west coast of Gotland (Gustavsson, 1991).

In the English 'island', two linguistic streams flow together. One leads from the protoIndo-European source, via Germanic and Old Norse to pre-English 'ēaj', Anglo Saxon and Old English 'ieg', 'ig', 'eg' ('igoð', 'iggath', 'igeth' are Anglo-Saxon and Old English for a small island). In the oldest written sources, from the $9^{\text {th }}$ century, the spelling is 'iland', 'igland' or 'ealond', (a riverland, a watered place or meadow by a river). ${ }^{13}$ Thus, John Donne's famous phrase from 1624 originally was "No man is an Iland" (Donne, 1624; also quoted in Royle, 2007:34) The other stream leads us to considerably younger Roman confluents. The modern English 'island' appears in the $15^{\text {th }}$ century and becomes established by the end of the $17^{\text {th }}$ century. According to The Dictionary of the English Language, the added ' $s$ ' "is due to a mistaken etymology, confusing the etymologically correct English iland with French 'isle' or 'île'. The English linguist John Barton comments: "So the spelling was altered by misguided pedants, but they were powerless to change the pronunciation". 14

9 http://dictionary.reference.com/browse/island. Hellquist (1980: 1451f). SAOB: insel.

10 Grimm, J \& W 1854-1960: Band 3, Spalten 105-110.

11 Royle (2007:33); http://palimpsest.stanford.edu/byform/mailing-lists/exlibris/2001/08/msg00094.html, http://de.wikipedia.org/wiki.eiland; http://en.wikipedia.org/w/index.php?title=Ait\&oldid=301861093; Hellquist (1980:1451f).

12 Royle (2007:35) has a comprehensive map of the British Isles.

${ }^{13} \mathrm{http}: / /$ www.worldwidewords.org/weirdwords/ww-eyo1.htm.

14 "island." Online Etymology Dictionary. Douglas Harper, Historian. island. Dictionary.com. Dictionary.com Unabridged (v 1.1). Random House, Inc. http://dictionary.reference.com/browse/island. http://palimpsest.stanford.edu/byform/mailing-lists/exlibris/2001/08/msg00116.html. 
Both these linguistic streams combine with a third, '-land', or 'lond', from Indo-European 'lendh', via proto-Germanic 'landom'. The original meaning seem to have been "a definite portion of the earth's surface owned by an individual or home of a nation". Also in mediaeval Sweden the word was used in this sense. Småland ("small land"), a county in south Sweden, was originally a number of small 'lands', later united into a larger political unit. Later on, 'land' took on other meanings, as synonyms to both 'earth' and 'country'. ${ }^{15}$

The French word for island, 'isle', 'île', as Spanish 'isla', Italian 'isola', Portuguese 'ilha' and other Romance (Romanic) equivalents, all stem from the Latin 'insula', a word of uncertain origin. While some linguists have pointed to Old Greek 'v $\eta \sigma o \zeta$ ' ('nēsos', island $^{16}$ ), others have sought a relation to Latin 'sōlus', alone, either via the feminine adjective 'insulus', reflecting the Old Latin phrase "en salos" (in the open sea"), elliptically from 'terra in salo' ("land in the sea"), or from 'terra insola' ("land by itself"). ${ }^{17}$ Interestingly, 'insula' was not necessarily defined by surrounding water. The Romans used 'insula' for a number of places, with or without surrounding water. Living quarters for the middle and lower classes in Rome, the plebs, was called 'insulae'. Medieval Marseille was administratively divided into 'insulae', supervised by a tax collector called 'insularis' (Gillis, 2004:15).

From Latin, English and Romance languages have also 'peninsula', originally 'paeninsula', "almost island". In English literature 'insularity' ("of or pertaining to an island") appears in 1611, a time when islands expressed connection, belonging and community, and when "the British came to think of themselves archipelagically" (Edmond \& Smith, 2003:15). Historian John Gillis (2004: 112) writes:

"In the $18^{\text {th }}$ century, insular peoples were thought to be not only among the most free, but the most cosmopolitan and progressive people in the world".

To this, Edmond and Smith (2003:15) add that, in the poetry of the period:

"[T]ropes of the commercial, the archipelagic and the Britannic melded to celebrate an empire that was peaceful, prosperous and free. Liberty became an 'island-Goddess' whose home was Britain but whose influence bound together the scattered islands of Britain's spreading empire" (also Ellis, 2003).

By the middle of the $18^{\text {th }}$ century, after the continental turn in European geopolitics and economy, island became a metaphor for isolation and alienation. 'Insularity', in this metaphoric sense, as "narrow" or "prejudiced", enters English literature only in 1755 (Gillis, 2004:112). 'Insulate' offers a similar case. It appears in 1538 in the sense "make into an island", in 1742 "block from electricity or heat, and only from 1785 in the sense "cause a person or thing to be detached from surroundings". ${ }^{18}$ Also the Swedish equivalent 'isolera', a loan from Italian 'isolare', literally meaning "leave or place on an island", have

${ }^{15} \mathrm{http}: / / \mathrm{www}$. etymonline.com/index.php? search=inslular\&searchmode=none.

${ }_{16}^{16}$ From which the derivation of 'nissology', a term also meaning 'island studies'.

${ }_{17} \mathrm{http}$ ///en.wiktionary.org/wiki/insula.

18 http://www.etymonline.com/index.php?search=inslular\&searchmode=none. 
undergone the same kind of changes. It first appears in 1780, in a somewhat neutral sense, "alone, independent" or "single", but from early $19^{\text {th }}$ century it is used more negatively, "to detach, suspend, abridge" or "cut off (Hellquist, 1980: 414).

The modern Irish standard for island is 'oileán', from 'ailén', a newly-formed derivative of 'ail', 'rock'. In Old and Middle Irish, 'inis' was the standard (Welsh 'ynys'); a word still found in numerous placenames. The word has been superficially associated with Greek

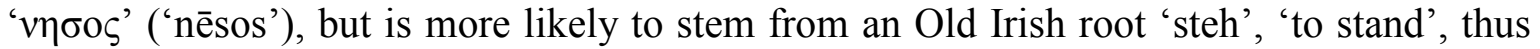
literally meaning 'standing in', maybe a reference "to the isolated appearance of an island in the sea"(Perdersen, 1976:192). ${ }^{19}$

In Finnish, island is 'saari'; in Estonian, 'saar', with equivalents in all other Baltic-Finnic languages, Karelian, Vepsian, Votic and Livonian. The Estonian island of Saaremaa is literally 'i-land', just as Åland, Öland and the English 'island'. The origin is unknown. The meaning is a piece of land that you can stand upon, or where trees grow, surrounded by water, or in a marsh. In Livonian the word is also used for 'potato patch', a "furrow or the ridge between furrows" (Häkkinen, 2004:1098). ${ }^{20}$ North Sami, also purportedly related to Baltic Finnic languages, has 'suolu' for island and the diminutive 'suolusj' for small island or holm. 'Suolo' may also refer to a mountain or elevation surrounded by lower terrain, as in Suolojvarre, a mountain surrounded by marshes in all directions, south of Jokkmokk, in north Sweden. ${ }^{21}$ Hungarian has 'sziget', derived from 'szeg', an old Finno-Ugric word for 'point', 'corner'. The original meaning was 'a pointy piece of land surrounded by water'. ${ }^{22}$

In many Slavic languages, the island-word is 'ostrov', (Belorussian 'vostraj', Ukranian 'ostriv', Serbian and Croatian 'ostrvo'), which stems from 'struja', stream, current. Russians write 'остров' and can thereby imply also a grove, an oasis or a dry place in a marsh. ${ }^{23}$ In Slovak 'ostrov' is documented in written sources as early as 1263 . A $15^{\text {th }}$ century Slovak loan is 'sihot" (river island, small peninsula, gravel bank), from Hungarian 'sziget', found in old place-names. From 'sihot' the adjective 'osihoteny', isolated was derived. 'Ostrow' is found in some Polish place-names, but in modern Polish island is 'wyspa', a word supposedly derived from 'wysyp' or 'nasyp', a small hill or hump (Brückner 1927). Some south and west Slavic languages, such as Slovenian and Czech, have 'otok', from Proto-Slavic 'tokъ', stream, flow.

In Latvian and Lithuanian, island is 'sala' (Karulis, 1992: 147). ${ }^{25}$ The original meaning is thought to be stream, river. The stem, 'sel', 'ser', means to flow. We find it in the Latvian rivers Salaca, Salate and Salica, and in names of lakes and marshes in Latvia and

19 E-mail from Dr Jürgen Uhlich, School of Irish and Celtic Languages, Trinity College, Dublin, Ireland.

20 E-mail from Klaas Ruppel, Dept. for Minority Languages, Research Institute for Languages of Finland.

21 E-mail from Olavi Korhonen, Department of Samic Language and Samic Studies, Umeå University. August 21, 2009.

22 A magyar nyelv történeti-etimológiai szótára. E-mail from Marianne Bakro-Nagy, linguist at Hungarian Academy of Science, March 3, 2009.

23 http://ru.wiktionary.org/wiki/octрoв.

24 E-mail from L'ubor Králik, Department of History of the Slovak Language, Ludovít Štúr Linguistics Institute, Slovak Academy of Sciences, Slovakia, March 10, 2009.

25 E-mail from Lina Būgienè, Institute of Lithuanian Literature and Folklore, Vilnius. 


\section{O. Ronström}

Lithuania, as well as in the Finnish 'salo' and Swedish 'sala' in place names in the Baltic Sea and Ostrobotnia. An old meaning is supposed to be 'something surrounded by water', the same original meaning as in the Slavic 'o-strov' (Fraenkel, 1955), later it became used also for 'a forested area' (Zilliacus, 1989: 49-50).

\section{Differences}

Words mirror ideas, perspectives and world-views: that was the starting point of this survey of a number of Western European island-words. So, what does such a survey tell us? Firstly, we have seen that all the different language families I have looked at have their own general words. There is no common source. This observation seem to support a reading of the different words as reflections of the world-views and perspectives of their users, which in turn, through careful studies of the words' accumulated semantic clouds and their histories, should make it possible to uncover knowledge otherwise not easily attainable; a kind of linguistic archaeology as it were. There is however also another, perhaps more feasible option that would blur such a reading: simply that many of the words are loans from surrounding languages. It has been suggested that, since proto-IndoEuropean lacked a maritime vocabulary, words relating to seas and islands, such as 'insula'

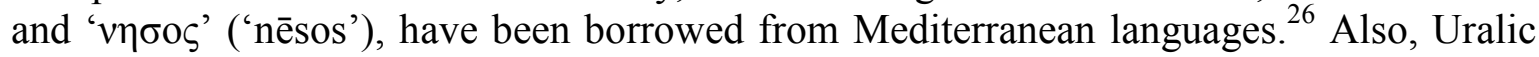
languages lack a common general island word, which can be explained by the great distance to seas and shores from the supposed original Uralic "Urheimat" in today's eastern Russia. It has been suggested that the different Uralic words for islands are either remnants of unknown proto-European languages spoken earlier in the region, more recent creations, or loans from neighbouring languages (Häkkinen, 2004: 1098)

Secondly, we learn that the somewhat pejorative connotations that some island-related words - such as 'isolate', 'insulate' or 'insular/insularity' - carry today may be fairly recent, at least in languages such as English and Swedish. ${ }^{27}$ There may be various reasons for this development. One, as explained by John Gillis, is the changed perspectives that followed the continental turn in European history in the late 18th century, when Atlantic islands moved from central to remote and peripheral, and became "islanded" in the modern sense (Gillis, 2001; 2004)

Thirdly, not surprisingly we find that in all the words covered there is a characteristic builtin opposition, a basic duality. Islands, at least linguistically, are constituted by the interplay between two radically different elements - land is what they consist of; water is what surrounds and defines them (Edmond \& Smith, 2003: 9). Which of these is emphasized varies. In Germanic, Slavic and Baltic languages, it is the water, the basic denotation of 'island' is water surrounding or flowing around a piece of land. In Hungarian, Finnish, Sami, Irish and Polish, it is the land surrounded or around which water is flowing that is

\footnotetext{
${ }^{26}$ Frisk (1970), Chantraine (1999), http://en.wiktionary.org/wiki/insula.

${ }^{27}$ Even in languages that do not use derivations of 'insula' for words like 'isolation' and 'insular', one can find equivalents made up from island-words. From the Hungarian 'sziget' are derived 'szigetelni', to isolate; 'szigetelés', isolation; and 'elszigetelni', to isolate from, cut off from, segregate. E-mail from Dr. Marianne Bakro-Nagy, linguist at Hungarian Academy of Science, Oct 30, 2009.
} 
emphasized. The common definition of 'island', 'a piece of land surrounded by water' is thus etymologically not entirely correct. In the latter languages it would be 'a piece of land surrounded by other kinds of land, or water', and in the former 'a water surrounding a piece of land'. And in all these languages, we have to imagine, there is an always present horizon of unbroken landmasses, mainlands, that renders the production of differences islands - meaningful.

Fourthly, and perhaps most importantly, we learn that whatever 'island' is, it seem to be all about difference. After all, language is nothing but differences: words relate to, express and produce difference. Language operates through relations of difference, which place signs, words, in opposition to one another (Saussure, 2006).

Islands are different. There are many islands in the world: a recent calculation gives 680 billion, and all of them different. ${ }^{28}$ Difference, however, is a somewhat indifferent phenomenon: it doesn't come in so many different ways. Difference can after all be produced only against a background of some kind of similarities. So what matters is not difference per se - there is simply too much of it - but differences that makes a difference (Bateson, 1972: 448-466). As Quammen puts it:

"Islands ... are unique and therefore they are normal. ... But throughout the world they manifest their differences in a handful of similar ways" (Quammen, 1996: 120; also Lundberg et al., 2000: 26f).

Such similarities depend on the defining perspective. From a bird's eye view, or from a mainland perspective, islands seem to be defined by boundedness and separation, the omnipresence of the great divider, the sea, and by what they are not, continuous, unbroken, connected. Godfrey Baldacchino notes that if a person is asked to draw an island as seen from the air on a piece of paper, most likely "that person would draw a stylized image of a piece of land, without much detail other than being surrounded by water. It would fit within the space confines of the sheet. It would also, uncannily, have an approximately circular shape." In view of the many islands, all of them different, why should this happen ${ }^{29}$ Baldacchino suggests:

"[Te answer] lies in an obsession to control, to embrace an island as something that is finite, that may be encapsulated by human strategy design or desire ... Is it the boundedness and separation that makes islands so attractive to fantasy and mythology? Circular forms make the exercise easier, as well as somehow more perfect" (Baldacchino, 2005: 247).

Representing islands make them different in similar ways. 'The island' is a common metaphorical genre. Pete Hay suggests that the "metaphoric deployment of 'island' is, in

\footnotetext{
${ }^{28}$ Depraetere \& Dahl (2007:68). The number relates to pieces of land larger than $0.1 \mathrm{~m}^{2}$.

${ }^{29}$ Baldacchino continues: "Nor are islands circular. Actually none of them are; moreover - other than planet Earth from Space - very few get close" (2005:247) This might be true, if taken literally. However, there are a number of islands that do get rather close to circular, such as Lilla Dalö in an archipelago south of Stockholm (Källgård, 2005b:320).
} 
fact, so enduring, all-pervading and commonplace that a case could reasonably be made for it as the central metaphor within western discourse" (Hay, 2006: 26). Hay finds three main faultlines in island studies, islands as detached and bounded versus connected and permeable; stability and community versus migration and flux; and islands as real, natural versus "of the mind", constructs, representations (Hay, 2006). John Gillis sees the island as a master metaphor capable of representing a multitude of things: fragmentation and vulnerability, wholeness and safety, loss and recovery, paradise and hell, quarantine, exile and asylum, separation and continuity, isolation and connection, past and future, origins and extinctions (Gillis, 2004: 3). Islands are common also for other rhetorical purposes. "Islands are synecdoches", writes Godfrey Baldacchino, "their understanding facilitates a 'coming to grips' with a more complex whole. ... As prototypical ethno-scapes, islands spearhead the study of the production of locality" (Baldacchino, 2007: 9, 16). Baldacchino (2005: 248) summarizes the position of much of island studies nicely:

"An island is a nervous duality: it confronts us as a juxtaposition and confluence of the understanding of local and global realities, of interior and exterior references of meaning, of having roots at home while also deploying routes away from home".

A nervous duality indeed: everywhere dualities, dichotomies. Island-words are built on dualities. Island metaphors and synecdoches are two-part relations that tend to come in pairs. The land-water dichotomy built into island-words, pictures and tropes, suggests a "natural" duality. But dichotomies and tropes are everything but "natural": they are tools for production of meaning that reduce and organize the world into a simple binary system. Too simple, for there is always an invisible third, or fourth, or fifth part hiding somewhere in the background. One of these invisible parts may be the mainland; others may be other islands, smaller or bigger ones, near or distant.

\section{Linguistic Relativity?}

What support does the principle of linguistic relativity get from a study of island-words in languages of North Western Europe? Do peoples with many islands around them also have many words for them? It certainly does seem that way. English, which is Royle's example, has a number of distinct words, and not just synonyms, for islands of different kinds: 'island', 'isle', 'islet', 'holm', 'reef', 'rock', 'eyot' or 'ait', 'atoll' and 'key'. These he sees as "marking the importance of the construct to a language which developed in an insular setting amongst a trading and colonizing people" (Royle, 2007: 33-39).

Finnish is another case in point. Like English, it is a language which developed in an insular setting, although Finns were never traders and colonizers as much as they were farmers and fishers. In Finnish culture and economy, not to speak of folklore, islands have played a decisive role. ${ }^{30}$ Marking the importance to the Finns of the many islands in the archipelago of Western Finland and Estonia, Finnish have many words for islands: either

30 The great Finnish epic Kalevala is situated in a mythological landscape where boats, rivers and islands play an important role. 
home-grown or loaned from other neighbouring languages. Beside the general 'saari' there are: 'arina', 'holma', 'hyyppä', 'kaarko', 'kalla', 'kari', 'karta', 'keidas', 'krunni', 'runni', 'kääppä', 'letto', 'luoto', 'saajo', and 'salo'.31

Do peoples on continents or those in countries with few islands also have few islandwords? So it seems. Latvians and Lithuanians have their 'sala'; Germans 'insel' and sometimes 'eiland'. Royle quotes examples from Slovenia and Slovakia, both countries with very few islands. Slovenes have 'otok'. Slovaks use 'ostrov', as do the Russians and a number of other Slavic peoples. Hungarians use 'sziget'. But, on the other hand, in many languages you can easily form diminutives with new meanings. In Slovakian, 'ostrovček' is a small island, but also a platform, as on a train or bus station. ${ }^{32}$ In Hungarian, 'szigetecske' is a small island. Combinations with other words create more options. In Hungarian, 'folyami sziget' is "river island", of which there are a few in the Danube; and 'szigetcsoport' is an 'island-group' or archipelago. ${ }^{33}$

\section{And what about Sweden?}

The islands of Sweden are many, no less than 221,800 according to Statistics Sweden (Ansén \& Justusson, 2001). ${ }^{34}$ If the many islands in the Swedish speaking areas along the west coast of Finland and in the Åland archipelago ("a puzzle of 3,000 patches of land over a surface of $15,000 \mathrm{~km}^{2}$ creates the world's highest density of islands" (Depraetere \& Dahl, 2007:71) is included, Sweden is probably second only to Canada as the largest islandnation in the world. Does Swedish also have many words for different kinds of islands?

Yes. Beside the general 'ö', (and a few words for islands in other parts of the world, such as 'atoll') I have found a large number of more or less commonly used words for islands of different size and use in dictionaries, maps and sea charts. 'Ö' seems to be by far the most common, followed by '-holme', -'holm'. Here the most common of these are tentatively listed according to size and frequency: ${ }^{35}$

holme, holm, an island, with some trees and other vegetation, often smaller and somewhat flatter than "islands", also a small hill or elevation over the ground, in a

31 E-mail from Klaas Ruppel, Department for Minority Languages, Research Institute for the Languages of Finland, March 9, 2009.

32 E-mail from Bernard Garaj, Nitra, July 15, 2009. The English 'island' can also denote a platform in a railway station or at a car service station. There is also a traffic island.

33 Shoal or sandbank is 'zátony', for reef it is possible to use also 'szirt': rock. E-mail from Marianne Bakro-Nagy, linguist at the Hungarian Academy of Science, March 3, 2009.

34 Källgård (2005a:295) relates the method: "In most parts of the country, the data were calculated from digital information on the scale 1:10,000, which means that 'islands' as small as $25 \mathrm{~m}^{2}$ were included. In some areas (typically close to the capital, Stockholm) even better maps were available, so that even smaller chunks of land were counted; on the other hand, in the high mountain regions in the north, the scale used was 1:50,000, so that only somewhat larger islands were included there."

35 Most of these words are from the Stockholm archipelago and the Archipelago Sea, by the help of Hedin (2007), Källgård (2005b), a website on placenames in the the Archipelago Sea and the coast of Western Finland by Kurt Zilliachus and Michaela Örnmark, (http://kaino.kotus.fi/svenska/ledlex), and e-mail from Per Sundgren, March 17, 2009, a sailing enthusiast and expert on the Stockholm archipelago. 
field or meadow. Over 6000 -holms are found in Skärgårdshavet, the Archipelago Sea and Western Finland. Most of the 1216 unbridged Swedish islands that have been or still are populated that Källgård (2005b) covers in his study of Swedish islands are named '-ö'. The second most common type is '-holm'. The word stems from Germanic 'hulman', via Old Swedish 'holmber'. It is related to 'kulmen', peak or highest point, which renders 'holme' similar to Hungarian 'sziget' and Polish 'wyspa'. ${ }^{36}$ The Vikings called a ritualized battle to resolve disputes 'holmgång'. This would be held on the limited space of a 'holm'.37

skär, a small island, with little or no vegetation, often a bare, naked rock. The 'Skärgård', literally a 'rock garden', is a stretch of water enclosed by small islands, an archipelago. In the Archipelago Sea, there are over 4,000 small rocky islands named '-skär'. The word is Old Norse and spread over large parts of Northern Europe. It is related to the verb 'skära' (scar, or cut) and may have referred to 'land cut apart'. In Anglo-Saxon it became 'score', from which English have both 'skerry', small rock island, and 'shore'. 38

ör, öra, ören, örel, stony bank or holm, sandbank, a graveled skerry (Vidings öra, Långören, Söderören). In parts of the Baltic Sea often a small rocky appendix to larger holms. There are around 3,500 places called '-ören' in the Archipelago Sea and the Swedish speaking parts of Western Finland, most of them surrounded by water. The word stems from Germanic 'aur': gravel, or small stone. ${ }^{39}$

kobbe, kobb, kobba, kubba, a rounded small bare skerry or rock, higher and steeper than for example a "grund" or a "kläpp". In the Archipelago Sea there are over 1300 places called '-kobbe', '-kobba'. In some places in this region, 'kobbor' are larger than 'kobbar'. The word is east Swedish, related to Icelandic 'kobbi', a young seal. It may also be related to English 'cob' and to Low German 'kobbe': a spider. $^{40}$

klubb, klobb, klobba, a rocky skerry, relatively high and steep, not necessarily surrounded by water, sometimes by a waterway or channel (Edöklubbar), in Ostrobotnia also forested hillside. There are around 1300 small rocky skerries or spits called '-klubb', 'klobbe' and so on in the north-east part of the Archipelago Sea. $^{41}$

båda, både, a low shallow rock or bank (Vitbådan, Norrbådan). Well over 1000 small rocks are named '-båda' in the Baltic sea. The word is believed to be related to the verb 'båda' (as in 'förebåda', portend, augur, foreshadow) and may have

\footnotetext{
Hellquist (1980: 241). http://runeberg.org/svetym/1315.html SAOB (http://g3.spraakdata.gu.se/saob/)

8 Hellquist (1980: 773); Skerry, http://en.wikipedia.org/w/index.php?title=Skerry\&oldid=244963012. http://kaino.kotus.fi/svenska/ledlex/S.php\#Sk\%C3\%A4ru-.

39 Hellqvist (1922: 1237); http://kaino.kotus.fi/svenska/ledlex/O1.php.

${ }^{40} \mathrm{http}: / /$ kaino.kotus.fi/svenska/ledlex/K.php\#-kobba. Hellquist (1922: 334).

${ }_{41}$ http://kaino.kotus.fi/svenska/ledlex/K.php\#-klobb
} 
referred to an underwater shoal overflown by the sea. ${ }^{42}$

klack, either a small hill, often the top, or a a shallow rock just under the water surface. There are 250 places named '-klack' in Western Finland, some surrounded by water, some not. ${ }^{43}$

har, hara, hare, a stony bare rock, a smaller skerry or point (Dregelskärsharan, Långharan, Storharan). ${ }^{44^{\circ}}$

grynna, grynda, grund, a shallow rock just over or under the water surface. ${ }^{45}$ 'Grynna' is from 'grund', 'ground' in English, and in Old Swedish also used as a verb: to reach the bottom, to ground.

kläpp, a small rock just above the water surface (Långkläppen, Trutkläppen). Although similar to 'klippa' (rock) the word probably stems from 'klimp', which mean lump or nugget, but in some places is also used for a shallow, rounded rock. ${ }^{46}$

klabbe, klabb, small rock or skerry. The word is commonly used in Swedish for a short, thick piece of wood.

Beside these there are a large number of words used for small islands in Swedish speaking areas, such as -berg, mountain, rock, -bäling, a small island, maybe from "bullig" (Källgård, 2005b: 293) (adj, derived from 'bulle', bun), used for any kind of object with rounded contour; -löga; -garn; -hög, -högar, hillock or heap; klippa, -knuv, knalle variations of names for a steep hill or rock; rev, revel, reef; sten, -stenar, stone, stones, small rocks.

\section{Discussion}

The seemingly simple question 'what is an island' obviously has many answers, one of them being: it is just 'a word'. The words for islands in Swedish are many, as in Finnish and English; this might reflect the cultural significance of islands to the speakers of these languages. If so, we might conclude that the principle of 'linguistic relativity' is supported; at least when it comes to some of the languages in North West Europe. But, since cultural significance is such an elusive phenomenon, the number of available words, categories or distinctions may mean little or nothing.

${ }^{42}$ http://kaino.kotus.fi/svenska/ledlex/B.php\#B\%C3\%A5g(a)-.

${ }_{43}$ http://kaino.kotus.fi/svenska/ledlex/K.php\#-kobba

${ }^{44}$ http://kaino.kotus.fi/svenska/ledlex/H.php\#HAR.

45 SAOB grynna

${ }^{46}$ http://kaino.kotus.fi/svenska/ledlex/K.php\#KUBB(A). 
Somewhat ironically, Geoffrey Nunberg makes the point when he writes that:

"[while English] has twenty or more distinct adjectives that apply wholly to physical beauty (...), colloquial Italian has little more than the lone word 'bello' aided by a handful of diminutive suffixes" (Nunberg, 1995: 6).

Thus, Nunberg argues:

"Italians in consequence are very likely deficient in the perception of beauty: the visual aesthetic must seem to them as monochromatic and undifferentiated as a snowy landscape does to us. But then, you look at their sports jackets and at our sports jackets, and you sense that we may be missing something" (ibid.).

Another conclusion that can be drawn from the survey of island-words is that, in practice, which of a whole range of words is actually used for a particular 'piece of land surrounded by water' depends on many factors, amongst which are the following:

- Formation, material and outlook: While most island-words are used for continental islands, there are also others that seem to be reserved for oceanic islands. Shape matters, as do material: in Swedish there are words for islands that consist of rock, sand or gravel: for islands that are steep, flat or shallow; and for islands that are bare, forested or otherwise vegetated.

- Size: Huge landmasses surrounded by water, like Australia, are normally not considered islands. Greenland, also large, is often named an island. An 'isle', Royle notes, "is a small island, except on those occasions where it refers to a large island, such as Great Britain, or Ireland (Royle 1997:38). In Swedish the size of the landmass is indicated by the preposition: while you are in larger landmasses (such as mainlands), you are on smaller ones (such as islands). The underlying politics of such use of prepositions and suffixes for positioning can mark important nuances. Gotland is Sweden's largest island, and one of the largest in Europe. In or on? Gotlanders talk about themselves as on Gotland, underlining their difference, their islandness; but tourists frequently refer to themselves as being in Gotland, to the annoyance of many islanders. Russians use the prepositions ' $v$ ' (in) and 'na' (on) + locative to denote the same difference: 'v Švecii' (in Sweden), but 'na Gotlande' (on Gotland). Ukraine is an exception: Russians say 'na Ukraine', to the annoyance of many Ukrainians, who interpret such usage as offensive. Ukrainians themselves tend to say 'v Ukraine'.

- History: Through land elevation many small islands in the Baltic Sea (such as 'skär', 'kobbar' and 'grynnor') have become considerably larger. In these parts, naming practices are often more stable than fundamental geological conditions: some skerries or banks are now more like holms, and some holms, like those which combine to make up Sweden's capital city, Stockholm, are now more like islands. Most of these are still recognized by their old names. 
- Distance: Distance to mainlands or to other islands is often decisive. Royle writes that to the Vikings the distance to a proper 'ey' or island was such that it was navigable by a ship with a rudder in place (Royle, 2007:40) Along the coast of Gotland there are several small islands nearby 'storön', "the large island" or "mainland". Most of them are 'holms', from the tiny Heligholmen to the larger Skenholmen. Karlsöarna, on the east coast, are smaller than the largest holms but further out, which seems to be a reason for naming them islands.

- Function and use: Pieces of land with vegetation enough to sustain a population, of people or cattle or both, are often islands or holms; those without are more often skerries, rocks, banks. In the 1861 Scottish census, islands are recognized as places with "sufficient pasturage to support at least one sheep" (King, 1993; also quoted in Royle, 2007:40).

- Economy: The UN defines islands as naturally formed areas of land surrounded by water and which remain above water at high tide. Rocks that cannot sustain human habitation or economic life are excluded, which turns most of the vast archipelagos in the Baltic to 'non-islands'. Royle's example is Rockall, west of Scotland: an "oceanic crag ... small enough to have been mistaken for an enemy ship" (Royle, 2007:40), but declared an island to support the British claim to exclusive exploitation of the Atlantic zone around it.

- Perspective: Islands are important cultural phenomena, master metaphors and synecdoches (Gillis, 2004; Hay, 2006; Baldacchino, 2007). Just about anything can be an island: if no man is an island, still an oasis, a garden, a paradise, a living quarter, a minority, a part of the brain, a platform, a planet can be named an island. Islands are perspective-dependant, born in the eye of the beholder: "This unit of land which fits within the retina of the approaching eye is a token of desire" (Hamilton-Paterson, 1993: 63, quoted in Royle (2007: 43). If they do not fit, we can always make them fit. Downsizing requires only a small change of the magnification of the lens.

- Politics: 'Small' is a common attribute to many economically unimportant places, irrespective of their natural' size. In places such as islands things are often diminished: cities become small towns, towns villages, houses cottages... "Downsizing is one of the ways we regain control of our lives", writes John Gillis (2004: 152). Miniaturization is a common technique for taking control of "the other' in exhibitions, museums, Disneylands, souvenir shops. In a study on longing, Susan Stewart argues that "the miniature offers a world clearly limited in space, but frozen and thereby both particularized and generalized in time (1993: 8). Again, Gotland provides a good example: despite its size, to most summer tourists it is definitely "a small place", with a simpler, slower of life. 


\section{O. Ronström}

\section{Conclusion}

What, then, is an island? The first and last answer: definitely a word. Words are magically tensile forms, differentiations according to formation, material, outlook, history, distance, size, function, use, economy, perspective and politics can be combined in many ways, and "stored" in words and combination of words. The only possible lesson to be learned is that the quest for definition is futile, because words, categories, meanings are situational and relative, or better, relational. Any linguistic system is a series of differences of sounds combined with a series of differences of ideas, and what any such system is about is differences that make a difference (Saussure, 2001; Bateson, 1972). What the first list of island-words I have discussed shows is that islands are made from such differences; that an 'island' is difference. The second list, the survey of Swedish island-words, takes this simple observation further, demonstrating how islands are related not so much as oppositions or dyads, but as endless series of differences from large to small, important to trivial, central to marginal, near to remote, and so on. These findings, however small and trivial they may themselves be, seem to support the idea that islands do not fit well into the common practice of constructing binary oppositions.

What alternatives are there? One is to combine oppositions and stretch them out into complex fields of tension or "cultural energy fields", a method I and two colleagues used in a large study of music, media and multi-culture (Lundberg et al., 2000). Another is seriality: if islands are dualities, they come in series of oppositions, or dichotomies. A series can be made up of several kinds of relations. One such relation, which could at the same time incorporate and expand the many "nervous dualities" and binary oppositions of island studies, would be a chain of dyads, either as in a number of connected dichotomies or metaphors, or as in a number of connected synechdoches or metonymes, where every position is connected to the other as a part to the whole. A specific form of this latter kind of seriality (which for some purposes may be seen as an alternative) is fractality. Depraetere and Dahl note that several authors, among them Mandelbrot, "suggest that the world looks like a fractal surface with inherently similar properties that are shared at various scales". They find that islands:

"... present an obvious hierarchy according to their size. This leads to the notion of mainlands surrounded by smaller units, whatever the scale considered" (Depraetere \& Dahl, 2007: 59).

The conclusion is that "changing magnification will still result in typically large but few chunks of mainland plus smaller but more numerous islands, both set up in a largely aquatic frame" (Depraetere \& Dahl, 2007: 64). The implications of such findings have yet to be integrated into island studies at large.

Baldacchino sees a new future for island studies based on knowledge on islands. "There may be no better comparison for an island than another island", he claims, and goes on to argue that the "fragmented (continental) narrative of the many islands of the world can be profitably replaced by a reclaiming, pan-archipelagic script of "a world of islands" (Baldacchino, 2007:17). I support this view, but I argue that such a script must be based on a discourse that does not in effect reduce this world of islands to mere oppositions and 
dualities. To accomplish this, it seems clear to me that one would have to start by examining the words in use, and then go on to expand the terminologies, categories and root metaphors of Island Studies, to allow for the inherent complexity in, and of, the 'world of islands'. Necessarily, any 'world of islands' is also a linguistic archipelago: a 'world of words'.

\section{References}

A magyar nyelv történeti-etimológiai szótára (1976) [Historical-etymological dictionary of the Hungarian language], Vol. 3. Edited by L. Benkő, Budapest, Akadémiai Kiadó.

Andersson, L.-G. (2001) Språktypologi och språksläktskap [Language, Typology and Language Relations] Stockholm, Sweden, Liber.

Ansén, H. \& Justusson, B. (2001) ‘Öar i Sverige: Sveriges Officiella Statistik' [Islands in Sweden: Sweden's Official Statistics], Statistiska meddelanden, MI 50 SM 0101, Stockholm, Sweden, Statistiska Centralbyrån.

Baldacchino, G. (2007) 'Introducing a World of Islands' in G. Baldacchino (ed.) A World of Islands: An Island Studies Reader, Charlottetown, Canada and Luqa, Malta, Institute of Island Studies, University of Prince Edward Island and Agenda Academic, pp. 1-29.

Baldacchino, G. (2005) 'Islands: Objects of Representation', Geografiska Annaler, Vol. 87B, No. 4, pp. 247-251.

Bateson, G. (1972) Steps to an Ecology of Mind: Collected Essays in Anthropology, Psychiatry, Evolution, and Epistemology, Chicago IL, University Of Chicago Press.

Boas, F. (1911) 'Introduction' in F. Boas (ed.) Handbook of American Indian Languages. Washington DC: Government Printing Office, http://www.archive.org/details/handbookamerica00fracgoog.

Brückner, A. (1927) Słownik etymologiczny języka polskiego [Etymological Dictionary of the Polish Language], Kraków, Poland.

Chantraine, P. (1999) Dictionnaire étymologique de la langue grecque: Histoire des mots [Etymological Dictionary of the Greek Language: A History of Words], Paris, Klincksieck.

Cole, D. (1999) Franz Boas: The Early Years, 1858-1906, Vancouver BC, Douglas and McIntyre.

Depraetere, C. \& Dahl, A.L. (2007) 'Island Locations \& Classifications' in G. Baldacchino (ed.) A World of Islands: An Island Studies Reader, Charlottetown, Canada and Luqa, Malta, Institute of Island Studies, University of Prince Edward Island and Agenda Academic, pp. 57-105. 
Donne, John (1624) Meditations XVII, http://www.online-literature.com/donne/409/.

Edmond, R. \& Smith, V. (eds.) (2003) Islands in History and Representation, London, Routledge.

Ellis, M. (2003) 'The Cane-land Isles: Commerce and Empire in late Eighteenth Century Georgic and Pastoral Poetry' in R. Edmond \& V. Smith (eds.) Islands in History and Representation, London, Routledge, pp. 43-62.

Fraenkel, E. (1955) Litauisches etymologisches wörterbuch [Lithuanian Etymological Dictionary], Heidelberg, Carl Winter.

Frisk, H. (1954-1972) Griechisches etymologisches wörterbuch [Greek Etymological Dictionary], Band 2. Heidelberg, Carl Winter.

Gillis, J.R. (2001) 'Places Remote and Islanded' in R.E. Greese \& J.R. Knott (eds.) Reimagining Place, Michigan Quarterly Review, Vol. 40, No. 1, pp. 39-58.

Gillis, J.R. (2004) Islands of the Mind: How the Human Imagination created the Atlantic World, New York, Palgrave Macmillan.

Grimm, J. \& W. (1854/1960) Deutsches wörterbuch [German Dictionary], Leipzig, S. Hirzel.

Gustavson, H. (ed.) (1991) Gotländsk ordbok [Gotland Yearbook] Visby, Sweden, Hanseproduktion.

Häkkinen, K. (2004) Nykysuomen etymologinen sanakirja [Modern Finnish Etymological Dictionary], Helsinki, WSOY.

Hamilton-Paterson, J. (1993) Seven-Tenths: The Sea and its Thresholds, London, Vintage.

Hay, P. (2006) 'A Phenomenology of Islands', Island Studies Journal, Vol. 1, No. 1, pp. $19-42$.

Hedin, A. (2007) Sveriges sjökartor: 1539-1836 [Swedish Seamaps: 1539-1836], Stockholm, Sweden, Max Ström.

Hellquist, E. (1980/1922) Svensk etymologisk ordbok [Swedish Etymological Dictionary] Lund, Sweden, C.W.K. Gleerups förlag, Berlingska.

Humboldt, W. von (1836/1999) On Language: On the Diversity of Human Language Construction and its Influence on the Mental Development of the Human Species, $2^{\text {nd }}$ revised edition, Cambridge, Cambridge University Press. 
Karulis, Konstantins 1992: Latviešu etimologijas vārdnīca: divos sējumos [Latvian etymological dictionary], Riga, Avots.

King, R. (1993) 'The Geographical Fascination of Islands' in D.G. Lockhart, D. DrakakisSmith \& J.A. Schembri (eds.) The Development Process in Small Island States, London, Routledge, pp. 13-37.

Källgård, A. (2005a) 'The Islands of Sweden', Geografiska Annaler, Vol. 87B, No. 4, pp. 295-298.

Källgård, A (2005b) Sveriges öar [The Islands of Sweden], Stockholm, Carlssons.

Lundberg, D., Malm, K. \& Ronström, O. (2000) Musik, medier, mångkultur. Förändringar $i$ Svenska musiklandskap, Gidlunds, Hedemora. English version (2003) available at: http://www.visarkiv.se/mmm.htm.

Malm, T. (2009) Den omöjliga kedjan. Människan och mångfaldens mönster [The Impossible Chain: Man and the Patterns of Diversity], Lund, Arkiv förlag

Modin, P. \& Palm, T. (2003) Lingvistisk relativitet och determinism: En utredning [Linguistic Relativity and Determinism], Kungliga Tekniska Högskolan. (www.nada.kth.se/kurser/kth/2D1418/uppsatser03/Sapir-Whorf.pdf.

Nunberg, G. (1995) 'Snowblind', Natural Language \& Linguistic Theory, Vol. 13, No. 1, pp. 173-179. http://people.ischool.berkeley.edu/ nunberg/snow.html.

Perdersen, H. (1976) Vergleichende Grammatik der Keltischen Sprachen [Comparative grammatics of the Celtic Languages], Göttingen, Vandenhoeck and Ruprecht.

Pullum, G.K. (1991) The Great Eskimo Vocabulary Hoax, and Other Irreverent Essays on the Study of Language, Chicago $\mathrm{IL}_{2}$ University of Chicago Press

Quammen, D. (1996) The Song of the Dodo: Island Biogeography in an Age of Extinctions, London, Pimlico.

Royle, S.A. (2007) 'Island Definitions and Typologies' in G. Baldacchino (ed.) A World of Islands: An Island Studies Reader, Charlottetown, Canada and Luqa, Malta, Institute of Island Studies, University of Prince Edward Island and Agenda Academic, pp. 1-29.

Ryd, Y. (2007) Snö: Renskötaren Johan Rassa berättar [Snow: Reindeer-breeder Johan Rassa recalls], Stockholm, Sweden, Natur \& Kultur.

Saussure, F. de (2001) Course in Literary Theory: An Anthology, edited by M. Ryan \& J. Rivkin, Oxford, Blackwell.

Saussure, F. de (2006) Writings in General Linguistics, Oxford, Oxford University Press. 
SAOB Svenska Akademins Ordbok [Swedish Academy's Dictionary] http://g3.spraakdata.gu.se/saob/.

Suomen sanojen alkuperä. Etymologinen sanakirja. Nos. 1-3. [The Origins of Finnish Words: Etymological Dictionary] edited by E. Itkonen \& U.-M. Kulonen, SKS, Helsinki, 1992-2000.

Whorf, B.L. (1974) Language, Thought and Reality: Selected Writings of Benjamin Lee Whorf, edited by J.B. Carroll, Cambridge MA, MIT Press.

Zilliacus, K. (1989) Skärgårdsnamn [Archipelago names] Skrifter utgivna av Svenska litteratursällskapet i Finland, No. 558. Helsingfors, Forskningscentralen för de inhemska språken. 